\title{
ECOTOURISM: A NEW HORIZON TO BANGLADESH
}

\author{
[ Mohammad Osman Gani, Ummya Salma, Md Arman Ali]
}

\begin{abstract}
Ecotourism is one of the fastest growing industries in the world. It is a form of natural resources based tourism focused on experiencing and learning about nature. Bangladesh is a land of diverse forest-based natural attractions throughout the evergreen, semi-evergreen, and diverse site with ecosystems. Facilitate with cheap transportation, lodging and associated costs, recreational activities, unique scenic beauty and wilderness of all sites and sociocultural diversity of indigenous communities living in the forest together make up the strength of the industry as a whole. In this study we attempt to explore various dimensions of ecotourism industry and critically analyze site and products of ecotourism as well as principles, factors, and goals that are directly related with eco-tourism.
\end{abstract}

Keywords- Ecotourism, forest-based, wilderness, socio cultural, ecosystems.

\section{Introduction}

Ecotourism has the ample opportunity to forward the development of our country in a distinguish markup. Rahman(2010) describes that, tourism and environment are co-related and inter-dependent. The physical environment of any country provides lots of attractions for tourists for that reason the diffusion of tourism industry with ecobalance comes up with some obvious benefits and costs in terms of environment, society, culture and development. Bangladesh is endowed with so many natural beauties like sea beaches, parks, forests, eco-tourism, wild life sanctuaries, hill tracts areas, tea estates, and islands etc. Over the last two decades, ecotourism activities have been expanding rapidly through worldwide and further growth is expected in the future. It has a global importance for that reason; the United Nations designated the year 2002 as the International Year of Ecotourism (IYE). Bangladesh is known as the world's largest green delta that filled with various natural wanders and untouched and unspoiled reserves, is a tremendous destination for ecotourism having unique and magnificent creatures.

Mohammad Osman Gani

Lecturer, Department of Marketing

Faculty of Business Studies

Bangladesh University of Professionals (BUP)

\section{Ummya Salma}

Lecturer, Department of Management

Faculty of Business Studies

Bangladesh University of Professionals (BUP)

\section{Md Arman Ali}

MBA (Finance), University of Dhaka

Vice President, Relationship Management

Corporate Banking,

The Hongkong and Shanghai Banking Corporation Ltd (HSBC)

\section{Rationale of the Study}

Tourism is a thrusting sector in our countries. It contributes to three high-priority goals of any country; income generation, employment creation, and foreign exchange earnings. Now-a-days ecotourism signifies as an important matter for the development of our country. A large portion of GDP and tourist distinctions generates from this sector. There is huge prospect of eco-tourism industry in Bangladesh. This industry will survive for a long time if the industry is properly treated. To continue the growth and sustainability of this industry we need to study about the sites and products of this industry, factors and scope relating with this industry, principles and goals regarding the industry is crucial. Finally, We want to study the potential of this industry by identifying the problems and addressing the some recommendations.

\section{Literature Review}

Ecotourism is a form of tourism which fosters environmental principles, with an emphasis on visiting and observing natural areas and living. Ecotourism inspired primarily by the natural history of an area, including its indigenous cultures. The ecotourist visits relatively undeveloped areas in the spirit of appreciation, participation and sensitivity (Kusler, J. A. ,2001) The eco-tourist practices a non-consumptive use of wildlife and natural resources and contributes to the visited area through labor or financial means aimed at directly benefiting the conservation of the site and the economic well-being of the local residents' (Donohoe, H. M., Needham, R. D., 2006) According to World Tourism Organization (WTO) in 2001, Eco-tourism is used to define forms of tourism which have the following characteristics quoted from Shermeen and Sultana (2011) that:

1. All nature-based forms of tourism in which the main motivation of the tourists is the observation and appreciation of nature as well as the traditional cultures prevailing in natural areas.

2. It contains educational and interpretation features.

3. It is generally, but not exclusively organized by specialized tour operators for small groups. Service provider partners at the destinations tend to be small locally owned business.

4. It minimizes negative impacts upon the natural and sociocultural environments.

5. It supports the maintenance of natural areas which are used as eco-tourism attractions by-

a) Generating economic benefits for host communities, organizations and authorities managing natural areas with conservation process.

b) Providing alternative employment and income opportunities for local communities

c) Increasing awareness towards the conservation of natural and cultural assets, both among local and tourists. 
Ecotourism provides a way to encourage preservation of the environment through reforestation, conservation areas, renewable resources, and recycling. According to McCormick (1994) ecotourism is defined as " a purposeful travel to natural areas understand the culture and natural history of the environment, taking care not to alter the integrity of the ecosystem, while producing economic opportunities that make the conservation of natural resources beneficial to local people". International Union for the Conversation of Nature (IUCN) defines Eco-tourism as: "Environmentally responsible travel and visitation to relatively undisturbed natural areas in order to enjoy and appreciate nature that promotes conservation, has low visitor impact and provides for beneficially active socio-economic involvement of local populations".

Bangladesh is an attractive ecotourism destination in south Asia. The natural attractions of Bangladesh are: the tropical climate, tropical beaches and sea, tropical forests, many rivers and lakes, beautiful tranquil scenery etc. (Bhuiyan, 2010). The country enjoys a sub-tropical monsoon climate characterized by rain-bearing winds, moderately warm temperatures, and high humidity. Bangladesh has possess some unique natural resources of global significance such as the world's largest mangrove forest, the largest unbroken sea beach, a unique landscape set in the world's largest alluvial delta with flora and fauna, truly hospitable and friendly people. Bangladesh having various kinds of natural variations e.g., hilly areas, sea beaches, mangrove forest and many historical places, has a huge potential in the scenario of world tourism. Ecotourism in Bangladesh is increasing in popularity as more people come to appreciate the stunning landscapes, fascinating wildlife, as well as biodiversity of plants found in this beautiful country. With hills, valley, forests, beaches, lakes and rivers ecotourism in Bangladesh is ideal.

A brief review of literature on eco-tourism shows that the issue has been studied to find out the tourist destination of our country. A lot comprehensive study has been conducted to depict the issue more vivid

\section{iv. Site, and Types of Ecotourism in Bangladesh}

Bangladesh is a country filled with natural wonders and untouched reserves and home to a variety of unique and magnificent creatures. Although this is still a relatively new form of tourism in Bangladesh, ecotourism is on the rise and extensive efforts are being made to promote it in the country. Bangladesh is blessed with two of the world's splendid and enchanting ecotourism spots of diverse nature- the Sundarbans and the Chittagong Hill Tracts.

Table 01. Popular Forest Based Tourist Spots with Area and Year of Establishment

\begin{tabular}{|l|l|l|l|}
\hline Name & Forest type & Area & Year of est. \\
\hline Sunderbans (W) WS & Mangrove & 71,502 & 1996 \\
\hline Sunderbans (W) WS & Mangrove & 31,226 & 1960 \\
\hline Sunderbans (W) WS & Mangrove & 36,970 & 1996 \\
\hline Lawachara & Hill forest & 1250 & 1996 \\
\hline Rema-kalenga WS & Hill forest & 1795 & 1996 \\
\hline Satchari WS & Hill forest & 743 & 2006 \\
\hline Chunti WS & Hill forest & 7764 & 1986 \\
\hline Teknaf GR & Hill forest & 11615 & 1983 \\
\hline Bhawal NP & Sal forest & 5022 & 1974 \\
\hline Madhupur NP & Sal forest & 8436 & 1962 \\
\hline Ramsagar NP & Sal forest & 28 & 2001 \\
\hline Hilsagar NP & Hill forest & 1729 & 1980 \\
\hline Kaptai NP & Hill forest & 5464 & 1999 \\
\hline Najhum Dip NP & coastal & 16352 & 2001 \\
\hline MedaKachchapia NP & Hill forest & 396 & 2004 \\
\hline Khadimnagarnp & Hill forest & 679 & 2006 \\
\hline Pablakhali WS & Hill forest & 45087 & 1962 \\
\hline Char kukri-mukri WS & Coastal & 49 & 1981 \\
\hline Fashiakhali WS & Hill forest & 1302 & 2007 \\
\hline Hazarikhil WS & Hill forest & 2908 & - \\
\hline Banskhali EP & Hill forest & 1200 & 2003 \\
\hline Madhabkunda EP & Hill forest & 266 & 2001 \\
\hline Kuakata EP & coastal & 5661 & 2006 \\
\hline Sitakunda EP & Hill forest & 808 & 1998 \\
\hline Madhutila EP & Sal forest & 100 & 1998 \\
\hline Dulahazara EP & Hill forest & 900 & 2006 \\
\hline National BG & Ex-situ & 84 & 1968 \\
\hline Sitakunda BG & Hill forest & 808 & 1991 \\
\hline Tanguar Haor & Swamp & 9725 & 1992 \\
\hline Hakaluki Haor & Swamp & 18,000 & - \\
\hline & & & \\
\hline
\end{tabular}

Source: BFD (2007), EP, Eco-Park, NP, National Park, GR, Game Reserve, BG, Botanic Garden, WS, Wildlife Sanctuary

\section{a) Khulna Division:}

In Khulna division people with interest to scenic beauty go there to observemangrove forest Sundarban and Shat Gambuj Mosque etc. The Sundarbans is the world's largest mangrove forest and could be the goldmine for ecotourism in Bangladesh. The mangrove forest in Sundarbans, with an area of 0.74 million hectors. The UNESCO has already declared Sundarbans as a world-heritage site with a view to preserving and protecting bio-diversity of the rare ecotourism. The Sundarbans mangrove forest, one of the largest such forests in the world, is formed at the delta of the Ganges, Brahmaputra and Meghna rivers on the Bay of Bengal. World famous Royal Bengal Tiger, spotted Deer, Otter squirrel, Monkeys, Barking deer, wild boar, Dolphin, reptiles, fish, birds etc. Hiron points, Katka, Kochikhali, Dubla Island, Mandarbari, and Putency Island etc are other important attractions of the Sundarbans. There are no permanent residents inside the Sundarbans although some 300,000-600,000 people earn their livelihood collecting honey, palm leaves, cutting grass, cutting wood, and catching and drying fish (FAO/UNDP, 1994).

\section{b) Chittagong Division:}

Chittagong is the commercial capital of Bangladesh. It is full of natural beauty. The mentionable ecotourism spots in Chittagong are Fay's Lake, Bandarban, Sitakundu, Parki 
Beach, Cox's Bazar, Himchori \&Inani Beach, Moheshkhali Island, Sonadia Island, St. MrtinsIsland, Nijhum Island, Teknaf, Hill tracks Rangamati, Cheera Island, Labonibeach.Cox's Bazar is the tourist capital of Bangladesh with a $186 \mathrm{~km}$ long sandy, straight and drivable beach (FFYP, 1997- 2002). Other special attractions of Cox's Bazar are Inani beach (about $30 \mathrm{~km}$ from Cox's Bazar full of coral stones), the island of Maheskhali (famous for its Buddhist and Hindu temples and a dry fish industry), Teknaf (the southern-most point of Bangladesh), Ramu, Sonadia, Himchhari, St. Martin Island (only Coral Island) etc.The three Hilly Districts of Rangamati, Khagrachari and Bandarban are inhabited by a number of tribes, with their distinctive cultures, rituals and traditions. Chimbuk, Ruma, Rain-Khyoung valleys, Keocradang and Tazinsdang are highly attractive in the hill tracts.

\section{c) Sylhet Division}

Sylhet is another division of Bangladesh having so many ecotourism spots to welcome tourists from across the country as well as from all over the world. Srimongol, Madhabkunda waterfall, Tea estate, Sylhet Lawacherra National Forest, Jaflong, and Tanguar Haor are mostly visited place by tourists. The Bangladesh Government plans to establish an Eco-Park in Moulvibazar district, which will take up more than 1.500 acres of Adivasi (indigenous peoples) ancestral land for tourism, named Lawachara National Park. It is a part of the West Bhanugach Reserved Forest; the reserved forest was established through an order under the forest act.

\section{Types of Ecotourism Sites}

\begin{tabular}{|c|l|}
\hline Types & \multicolumn{1}{|c|}{ Sites } \\
\hline Marine & $\begin{array}{l}\text { Marine-protected areas, coral reefs, islands, } \\
\text { beaches, bays }\end{array}$ \\
\hline Terrestrial & Mountains, volcanoes, caves, trails, forest areas \\
\hline Freshwater & Lakes, rivers, hot and cold springs, waterfalls \\
\hline Cultural & Churches, historic sites, festivals \\
\hline Manmade & Urban parks, reforestation sites \\
\hline
\end{tabular}

Source: Ahmed and Mollah (2014)

\section{v. Factors And Scope Of Ecotourism In Bangladesh}

Some of the factors effects more for developing ecotourism are:

a) Natural resources: Bangladesh is full of natural endowment and beauties. There are a lot of forest sites, rivers, water bodies, national parks and other natural sites are surrounding all over the country. These resources are the main attraction for developing ecotourism in the country.

b) Ecological specialization: Bangladesh has beautiful landscape and ecological sits. There are a lot of natural and ecological places all around the country, which have the immense power to attract the eco tourists.

c) Geographical importance: Bangladesh is the gateway of south-east Asia. It is connected by air and sea and by surface. It has tremendous strategic geographic advantages, which can immensely contribute the country to be an ideal ecotourism destination.

d) Topographical advantages: There are six seasons in Bangladesh such as summer, rainy, autumn, late autumn, winter and spring in Bangladesh. In every season, natures beautify her in different and unique ways which is exclusive in the world. So the delight of nature is a great source for ecotourism.

e) People involvement: mass people are emerging source for environmental education. Without their spontaneous participation, environmental teaching does not occur properly.

f) Government role: Government has played a vital role for sustainable ecotourism development. Govt. formulates necessary laws and regulations for maintaining ecotourism. Moreover, govt. can facilitate in environmental educational programs in tourist destination.

g) Organizational efforts: Organizational efforts are very effective for environmental awareness of society. Environment and tourism related government and nongovernmental organizations have taken initiatives in this regards.

h) International organizations: Some international organizations are working for raising the environmental consciousness to the people. Among them WWF, UNESCO, WCED, WCU, IES are mentionable.

i) Media: Media is a powerful weapon for building the society. Media can take part in ecotourism development and encouraging the people to environmental education.

j) Educational program: Environmental education provides the school with a positive approach to society, because environmental education helps the entire process of education.

k) Trained tour operators and guides: Tour operators and guides are trained up for operating ecotourism in light of environment friendly situation. If they trained up properly, they can ensure the effective ecotourism as well as environmental education.

1) Transportation Facilities: Different private organizations have their own transportation facility to deliver people by maintaining time schedule.

m) Hotel \& Motel Facility: Almost in very ecotourism places there are different hotel and motel are available at a reasonable price. The hotel and motels are also providing foods. For foreigners they are also providing different foods as they deserves and demands.

n) History and Heritage: Many historical and archaeological sites are situated in Bangladesh. Ancient mosques, temples, church, pagoda, shrines, historical buildings, different monuments are best examples of them.

o) Culture and Life Style: The ethnic life style of indigenous people of hill tracts, various religious and cultural shows are good forms of cultural diversity which might act as a powerful component of eco-tourism. 


\section{vi. Principles of Ecotourism}

a) Minimize the negative impact of nature and culture that can damage a destination.

b) Educate the travelers on the importance of conservation.

c) Stress the importance of responsible business, which work cooperatively with local authorities and people to meet local needs and deliver conservation benefits.

d) Direct revenues to the conservation and management of natural and protected areas.

e) Emphasizing the need for regional tourism zoning and for visitor management plans designed for either regions or natural areas that are slated to become ecodestinations.

f) Emphasize use of environmental and social base-line studies, as well as long term monitoring program, to assess and minimize impacts.

g) Strives to maximize economic benefit for the host country, local business and communities, particularly people living in and adjunct to natural and protected areas.

h) Seek to ensure the tourism development does not exceed the social and environmental limits of acceptable change as determined by researchers in cooperation the local residents.

Source: The International Ecotourism Society, 1991

\section{vii. Goals of Ecotourism}

Boo (2001) has recognized four goals of ecotourism, these are:

- Protection of the environment - Economies that are experiencing loss of resources due to population growth, hurricanes and extractive industries like fisheries, ecotourism can provide economic support for the protection of the environment.

- Economic sustainability- Economies that are facing the loss of revenue in the near future and rely heavily on imports, eco-tourism can provide a ready means of foreign exchange. The goals of eco-tourism are also to benefit residents by ensuring sufficient financial returns and an equitable distribution of costs and benefits.

- Cultural integrity and enhancement- The word 'ecology' in eco-tourism implies a two-way relationship between visitors and residents involving cultural exchange, but also mutual respect and reciprocity. If these elements are missing at a tourist destination, the warm welcomes could soon turn into resentment.

- Educational value- This can be seen in the education of both visitors and residents in creating awareness and appreciation of the natural environment and cultures, including what is passed down to the next generation.

\section{viii. Problems Related with Ecotourism in Bangladesh}

Some drawbacks might be pointed out as follows:

1) Lack of initial and psychological knowledge about ecotourism.

2) Lack of analyses on the existing miserable conditions.

3) Conflict between the tribal and other people.

4) Massive deforestation by different people.

5) Various destructive and unaware activities by the tourists like left-over food scraps and drinks.

6) Lack of effective promotional campaign both locally and internationally.

7) Lack of enough peripheral products .

8) Frequent natural calamity like flood, sidr, iila and so on.

9) Ethnic violence, terrorism and nationwide strikes are the social-political problems of ecotourism in Bangladesh.

10) Oppression of charitable countries and organizations, bureaucratic political and system also are the problems of ecotourism in Bangladesh.

11) Inadequate first-aid and service levels and untrained ground receiver are the service related problems of ecotourism in Bangladesh.

12) Lack of service, professionalism, ethics and erratic airlines schedule are also the service related problems.

13) Lack of relationship between service and proficiency, lack of well communication skills are the problems of ecotourism in Bangladesh.

14) Insufficient transport systems, lack of security, irresponsibility of agencies are also the problems of ecotourism in Bangladesh.

15) Insufficient tourism and airport infrastructure are the problems of ecotourism in Bangladesh.

\section{ix. Recommendations}

There are some recommendations that can be proposed:

1) Positive image of our tourism industry needs to be created by expressing to our diplomats, ambassadors, consular by representing Bangladesh in different countries of the world. Bangladeshi representatives staying abroad can act as overseas tour operators who can conduct inbound tours.

2) Billboard, leaflets, brochure, magazines and other marketing promotional materials can be displayed in different places in home and abroad.

3) People of the tourist's spots need to be informed about the attractions rich in history, culture, and heritage of the country.

4) Different beaches, rivers and other wetlands have to be facilitated with various establishment activities like river cruise, boating, beach volleyball, water skiing, fishing, etc. along with boatel based food and accommodation.

5) Adequate safety and security of the tourists should be ensured to remove negative image.

6) Tourism training institutes have to be established in a good number in different region so that they could produce skilled professionals to satisfy the needs and demand of the tourist.

7) Tourism adventures like trekking, hiking, mountaineering, hunting in different hilly areas need to be established by building up different clubs and organizations. 
8) We need to establish more eco-park, safari park and wildlife sanctuary especially in Sundarbans, Hill tracts and different potential areas like Dula Hazra and Madhab kunda.

9) Tourism facilities and services like accommodation, food and beverage, entertainments, travel agents, tour operations, shopping malls, supermarkets, transporters have to be established in good number ininternational standard in different tourist areas by public and private sectors.

10) Unexplored area like Parkirchar, Cheradip, Sandeed, and Hatia must be taken into consideration toexplored properly.

\section{x. Conclusion}

Bangladesh is a gift of nature. This country is an attractive ecotourism destination in south Asia (Bhuiyanet al.2010). Its natural resources, ecological advantages and situated in an important geographical nerve point are great pleasure for developing ecotourism here. Bangladesh has a host of tourist treasurers to offer to tourists- beaches, lakes, rivers, hills, forests, wildlife, tribal life, archaeological remains, including historical monuments, folklore, religious and cultural heritage, handicrafts and much more. All these combinations are enormous ecotourism products. The country, having tourism potential, must be conscious in developing market. The country has its potential to differentiate its product for its uniqueness. Therefore, ecotourism industry of Bangladesh must arrange its different elements such a way that give its better satisfaction to the visitors of the world.

\section{Reference}

[1] Ahmed, S. and Mollah, M., "A Framework for Classifying Ecotourism Initiatives in Bangladesh", Bangladesh Research Publications Journal, Vol. 9, Issue 4, pp.240-248, 2014.

[2] Bhuiyan, A. H. et.al. Ecotourism and Environmental Education: An Opportunity for Bangladesh, Proc. of International Conference on Environmental Aspects of Bangladesh (ICEAB10), Japan, Sept. 2010.

[3] Boo, E. Eco-tourism: The Potentials and Pitfalls, vol. I, Washington, D.C: World Wildlife Fund. 2001

[4] BFD Bangladesher Roskhito Bon Alaka : vormonnirdeshika (in bengali), Dhaka, Bangladesh Forest Department, Govt. of the people's republic of Bangladesh. 2007

[5] Donohoe, H. M., Needham, R. D. Ecotourism: The evolving contemporary definition. Journal of Ecotourism, 5 (3), 192-210. 2006.

[6] Kusler, J. A. Eco-tourism and Resource Conservation Project, Eco-tourism and ResourceConservation, A Collection of Papers.Madison: Omnipress. 2001

[7] McCormick, Kenneth "Can Ecotourism Save the Rainforests?" Rainforest Action Network, 1994, pp. 5663. 1994
[8] Rahman, M. "EXPLORING THE SOCIOECONOMIC IMPACTS OF TOURISM: A STUDY OF COX'S BAZAR, BANGLADESH", Cardiff School of Management University of Wales Institute, Cardiff, UK., 2010.

[9] Shermeen,S. and Sultana, $\mathbf{N}$ "Eco-Tourism in Bangladesh :Problems and Prospects" Dhaka University ,Journal of Marketing ,Vol.No.14, June 2011.pp-86-109, 2011.

\section{About Author(s)}

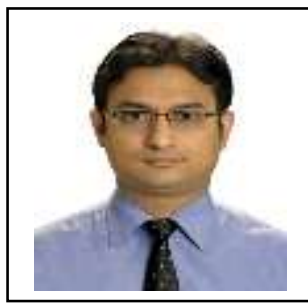

Mohammad Osman Gani has been serving as Lecturer of the Faculty of Business Studies (FBS) in Bangladesh University of Professionals, Mirpur Cantonment, Dhaka, Bangladesh. $\mathrm{He}$ is a graduate of Dhaka University. Also, he is an M.Phil Researcher at BUP.

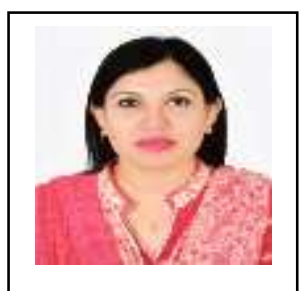

Ummya Salma has been serving as a Lecture of the Faculty of Business Studies (FBS) in Bangladesh University of Professionals (BUP), Mirpur Cantonment, Dhaka, Bangladesh. She is a graduate of Dhaka University. Also, she is an M.Phil Researcher at BUP. 